\title{
Botswana Unemployment Rate Trends by Gender: Relative Analysis with Upper Middle Income Southern African Countries (2000-2016)
}

\author{
Mufaro Andrew Matandare 1* \\ ${ }^{1}$ Faculty of Commerce, BA IS AGO University, P. Bag 149 Suite \# 268. Kgale View Postnet, Gaborone, \\ BOTSWANA
}

*Corresponding Author: mmatandare1@gmail.com

Citation: Matandare, M. A. (2018). Botswana Unemployment Rate Trends by Gender: Relative Analysis with Upper Middle Income Southern African Countries (2000-2016). Dutch Journal of Finance and Management, 2(2), 04. https://doi.org/10.20897/djfm/3837

Published: August 27, 2018

\begin{abstract}
This paper analyses Botswana labour market trends, specifically unemployment rate, over a period between 2000 and 2016. Furthermore, a comparison with Namibia and South Africa is done. To make an inference on unemployment rate by age and gender, it is vital to both consider the development and changes in the labour market over time. Botswana's unemployment rate was found to average $18.2 \%$ between 2000 and 2016. However a disparity between male and female unemployment rate was observed. Youth unemployment rate has been increasing over the study period in Botswana. Furthermore, youth unemployment in Botswana surpassed total unemployment in 2016. Botswana was found to have a more stable labour market in comparison with Namibia and South Africa. However, South Africa was commended for having the lowest female youth unemployment rate as compared to Botswana and Namibia. The findings further discerned an increase in economically active populace in all the countries. The paper suggests policies geared at easing entry into the labour market for youth especially females as well as for women. Diversification and investment in labour intensive industries should be a priority. Governments are also challenged to invest in relevant training and skills development which meets employers' needs.
\end{abstract}

Keywords: unemployment rate, labour market, Botswana, Namibia, South Africa

\section{INTRODUCTION}

Botswana is regarded as an upper middle income country, along with Namibia and South Africa, in the southern part of Africa. An upper middle income country has a per capita Gross National Income (GNI) ranging between US\$3 956 and US\$12 235 (World Bank, 2017). This essentially means that these countries are making huge strides in industrialization and urbanization. Residents of these countries on average enjoy a high or rather better living standard as compared to those of lower middle income and low income economies (Osei-Hwedie, 2003).

Industrialization and urbanization is associated with an increase in rural to urban migration as well as international or cross border migration, with urban areas and middle income countries being host to immigrants. The economically active population is the group which is regarded as "footloose" and thus migrate more resulting in an increase in the 15 to 64 years age bracket populace in receiving areas and countries (Sutherland, 2015). This results in unprecedented strain on resources and a surge in the unemployment rate.

Economically active population includes all persons of either sex who provide labour supply for the production of economic products (UN, 2002). Internationally, age 15-64 years is working age, and it is used by Statistical Office of European Union (Eurostat) and International Labour Organisation (ILO, 2012). Despite exhibiting 
phenomenal growth, Botswana has been marred by several socio-economic challenges with high unemployment rate considered as one of the socio-economic evils which has been proving difficult to deal with. Unemployment is indeed a serious problem in Botswana and its rates have been fluctuating from a low of 10.2 percent in 1981 to a high of 25.3 percent in 1984 (Malema, 2011); After declining steadily from 1984 onwards, the unemployment rate began to increase in 1991 (Hope, 1996); Later estimates have however shown unemployment to be decreasing since 1998. A Botswana Demographic Survey of 1998 estimates unemployment to have declined to about 19.6 per cent in 1998. The 2001 budget speech reports a further fall in unemployment to approximately 15.8 per cent in the year 2000 (Siphambe, 2007). A Botswana Aids Impact survey estimated unemployment to have risen slightly to 16.8 per cent in 2001 (CSO, 2002). After the turn of the millennium, unemployment rate in Botswana has been increasing hitting an all-time high record of 26.2\% in 2008 (World Bank, 2017).

This study's main objective is to analyze the unemployment rate trends of Botswana comparably with two other middle income countries in southern Africa, Namibia and South Africa. The analysis will border around gender.

\section{LITERATURE REVIEW}

The International Labour Organization (ILO) definition of unemployment covers people who are: out of work, want a job, have actively sought work in the previous four weeks and are available to start work within the next fortnight; or out of work and have accepted a job that they are waiting to start in the next fortnight. There are four major types of unemployment namely frictional, seasonal, cyclical and structural unemployment. Frictional unemployment is considered as not a serious problem and is unavoidable. This unemployment occurs when people move from one job in search of another job. It could also be new graduates entering the job market (Mohr et al., 2008).

Seasonal unemployment is associated with seasons. People are seasonal unemployed during the off-peak period in production. It is common in tourism, agriculture, retail and construction industries. Cyclical unemployment is also referred to as demand-deficiency unemployment. It is a situation where aggregate demand plummet causing industry to reduce production hence retrenching workers. Lastly structural unemployment is a result of a mismatch between the vacancies and the qualifications of the unemployed population. It is worsened by technology, imports, change of structure of an industry or economy as well as depletion of minerals (Mohr et al., 2008).

Various measures are put forward in trying to deal with the problem of unemployment. These include provision of in demand skills, providing information on job availability, government internship programmes, unemployment benefits, youth development programmes, entrepreneurial support and vocational training of technical and practical jobs. Nations cannot give a blind eye to unemployment as the effects are devastating and hard to miss. Individual level effects include loss of income, loss of self-esteem, loss of skill, reliance or criminal activities and prostitution, divorces among other socio-economic ills. At national level we cannot save labour services and use it in the future. A loss in GDP, loss in potential tax revenue as well as an unhappy nation is experienced (Mohr et al., 2008).

Traditional theories and contemporary theories and models have been propounded in a bid to explain the underlying causes, effects and dynamics of unemployment. Traditional theories include Marxist theory of unemployment. According to Karl Marx, unemployment is inherent within the unstable capitalist system and periodic crises of mass unemployment are to be expected. According to Marx, the only way to permanently eliminate unemployment would be to abolish capitalism. Classical theory of unemployment rests squarely on the microeconomic analysis of the labour market forces of supply and demand. Classical economists maintain that the economy is always capable of achieving the natural level of real GDP or output, which is the level of real GDP that is obtained when the economy's resources are fully employed. Keynesian Theory of Unemployment as proposed in the book The Theory of Employment, Interest and Money (1936), by Economist John Maynard Keynes (1883-1946) changed the way of the world's perception regarding the workings of the economy. First, Keynes introduced that the theory of the equilibrium is determined by aggregate demand. Decreasing consumer spending reduces demand for products, leading to a reduction in production, forcing companies to not only cut wages, but lay off employees. To solve the problem of unemployment Keynes proposed that the government should intervene into the economy (Skidelsky, 1992).

On the other hand, contemporary theories of unemployment include the efficient wage theory

The efficiency wage is the wage above equilibrium that firms voluntarily pay to increase. Critiques point out that eventually this produces higher wages for those who are employed but higher levels of unemployment. Contract models are based on the observation that labor contracts often forbid firms from changing wages in the short run, but allow them to respond to variations in their need for labor through layoffs and overtime. The contract is self-enforcing, meaning that neither of the two parties would be willing to breach the implicit contract in absence of any external enforcement since both parties would be worse off otherwise (Costas and Stiglitz, 1983). 
Search theory takes into account the heterogeneity/ differences of labor services and that describes the matching process of workers and firms. In the search approach, natural unemployment fluctuates when there are changes in the efficiency of matching in the economy or in the other flows between labor market places, Cahn and Zylberberg, 2004). Lastly the Inside-outside theory proposes that incumbent workers in the labor market, the "insiders," often enjoy more favorable employment opportunities than the "outsiders." The insider-outsider theory examines the behavior of economic agents in markets where some participants have more privileged positions than others. Those with privileges are able to hold on to their jobs while the outsiders will find it hard to break into the labour market. These theories all emphasizes the negative effects of unemployment and proposes different ways in which the problem of unemployment can be dealt with (Assar and Snower, 1986).

According to the World Employment and Social Outlook (2018) the global unemployment rate has been stabilizing after a rise in 2016. It is expected to have reached 5.4 per cent in 2018, with the total number of unemployed exceeding 192 million persons. As the long-term global economic outlook remains modest despite stronger than expected growth in 2017, the report attributes the positive trend between 2017 and 2018 mainly to the strong performance of labour markets in developed countries, where the unemployment rate is projected to fall by an additional 0.2 percentage points in 2018 to reach 5.5 per cent, a rate below pre-crisis levels. In contrast, employment growth is expected to fall short of labour force growth in emerging and developing countries, but has nevertheless improved compared to 2016 (ILO, 2018).

A panel study by Soylu et al. (2018) on the unemployment and economic growth issue using Panel Unit Root, Pooled Panel OLS and Panel Johansen Co-integration tests for Eastern European Countries for the period of 1992-2014 revealed that unemployment affected positively by economic growth. In other words 1\% rise in GDP will fall the unemployment rate by $0.08 \%$ because of Okun's coefficient for Eastern European Countries and there is a co-integration between these important macroeconomic variables.

On the other hand, Frank 1968's study on urban unemployment in Africa concluded that one of the characteristics of African countries is a rapid growth in urban population and urban workforce cobined with a much slowly increase in unemployment opportunities in the larger scale urban establishments. The result has been either unemployment or under-employment in small-scale, often individual or family-run, establishments. This phenomenon has been noted in countries with high population growth rates. Also those countries in Africa which are growing faster are affected by this phenomenon especially those ones failing to industrialize quickly.

An investigation of growth, jobs and poverty in Africa by AFDB revealed that most countries in this continent are marked by growth acceleration episodes followed by crisis episodes. This is considered failed take-offs, as in Algeria, Cameroon, Congo, Côte d'Ivoire, Equatorial Guinea, Ethiopia, Gabon, Malawi, Nigeria, Sierra Leone, Zambia, and Zimbabwe. In a failed take-off, the crisis often has economic roots, possibly related to characteristics of the previous acceleration episode that make it unsustainable (AFDB, 2018).

In Sub-Saharan Africa, the unemployment rate is expected to reach 7.2 per cent, essentially remaining unchanged in 2018. The number of unemployed should increase by 1 million due to the region's high levels of labour force growth. More than one in three workers is living in conditions of extreme poverty, while almost three out of four workers are in vulnerable employment (ILO, 2018). According to data from the International Labour Organisation (ILO) in Sub-Saharan Africa, the youth unemployment rate hovers around 12 percent. While this is slightly lower than the global youth unemployment rate of 12.4 percent, the African region has the world's highest rate of working poverty - people who are employed but earning less than US $\$ 2$ a day. Thus unemployment is a general problem in Africa and there must be a partnership between governments and the private sector to address it (Siphambe, 2007).

Botswana does not escape the challenge of unemployment: In 2017, almost three-fourths (73\%) of survey respondents cite a lack of jobs as one of the three most important problems that the government should address (Figure 1). Unemployment ranks well ahead of poverty/destitution (24\%), education (21\%), health (19\%), food shortage $(14 \%)$, and crime and security $(13 \%)$, while overall management of the economy $(10 \%)$ and other economic issues $(10 \%)$ come lower on the priority list. The economy of Botswana may be classified as uppermiddle-class, but the country still faces a number of challenges that are prominent in developing nations. Unemployment ranks at the top as a problem of increasing popular concern. While most Batswana are satisfied with the government's efforts to address education and youth needs and reduce poverty, high unemployment rate remains a thorny policy issues with direct implications for job creation.

According to World Bank Conference (2000), In the case of Botswana most of the $19.6 \%$ unemployed are relatively young people with low educational qualifications and no skill. With the employment mix becoming more skill intensive in both the private and government sectors, it means that each year more skilled workers are required relative to unskilled workers, as a result the problem of unemployment increases. Over the past few years there has been a rapid increase in youth unemployment. According to Morima (2012), Botswana youth unemployment rose from 11.8\% to $12.7 \%$ between 2008 and 2009. He further stated that, Botswana's youth unemployment is second highest in middle income countries. Youth unemployment in Botswana is higher than national 
unemployment which is currently at 17\% (Morima, 2012). The root cause of this level of unemployment is a failure to create enough jobs in the economy. Youth unemployment exceeds national unemployment (Bogale, 2014).

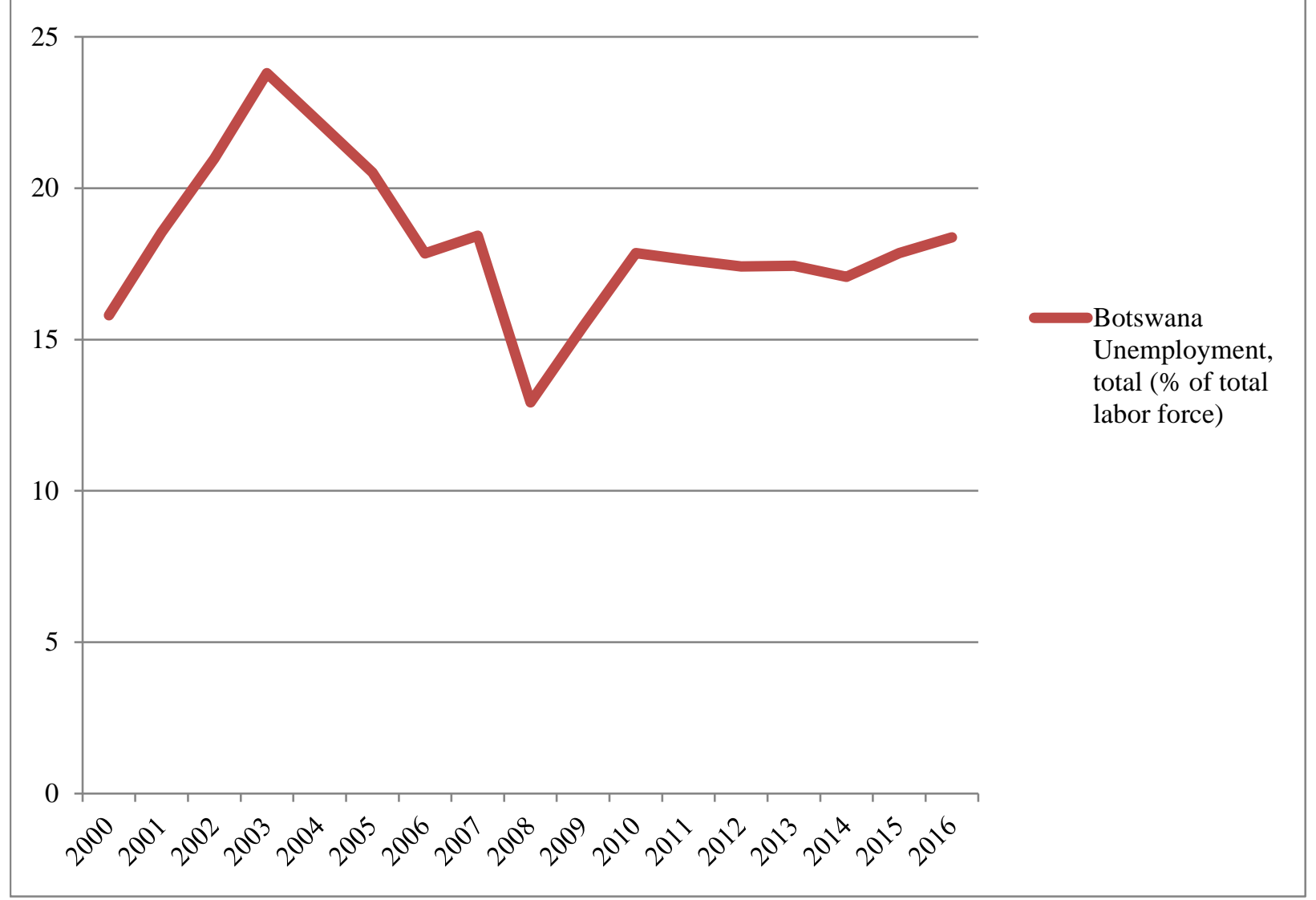

Figure 1. Unemployment Rate (Botswana, 2000-2016)

\section{METHODOLOGY}

To make an inference on unemployment rate by age and gender, it is vital to both consider the development and changes in the labour market over time. An analysis of the labour market indicators like economically active population, youth unemployment vis-a-vis total unemployment, labour participation rate and other trends is supposedly justified in this case. Needless to say, this is with respect to both aggregate level rates and gender gaps. Hence, for the sake of harmonized labor market data, in particular for comparison purposes as of this study, data analysis of trends of the unemployment rate by gender and age in Botswana, Namibia and South Africa is obtained from World Bank development indicators (2017).

\section{UNEMPLOYMENT RATE IN BOTSWANA}

Botswana became independent in 1966. At independence, Botswana was rated as one of the poorest countries in Africa. Within a period of three decades, Botswana had succeeded in emerging as an upper middle income developing nation with a per capita income annual growth rate of $8.4 \%$ (Nayaran et al., 2005). While Botswana has had good performance in terms of growth, its record in terms of employment is not that exceptional. Botswana has had periods of unrelenting high unemployment of about $20 \%$ for most of the 1990 s and early parts of the new millennium. Prudent macroeconomic management, revenue from diamond mining and good governance is accredited to the phenomenal economic growth rate experienced by Botswana (Siphambe, 2007). However, Botswana has not significantly managed to translate high economic growth to job creation. Diraditsile and Ontetse (2017) cited lack of diversification, a distribution of imports industry, capital intensive industry and an explosive population growth with a continually increasing economically active populace as some of the reasons contributing to a high unemployment rate. As shown on Figure 1, the unemployment rate of Botswana has consistently been a 2-digit figure averaging $18.2 \%$ between 2000 and 2016. Such an average figure is considered as high by international standards hovering around alarming. 


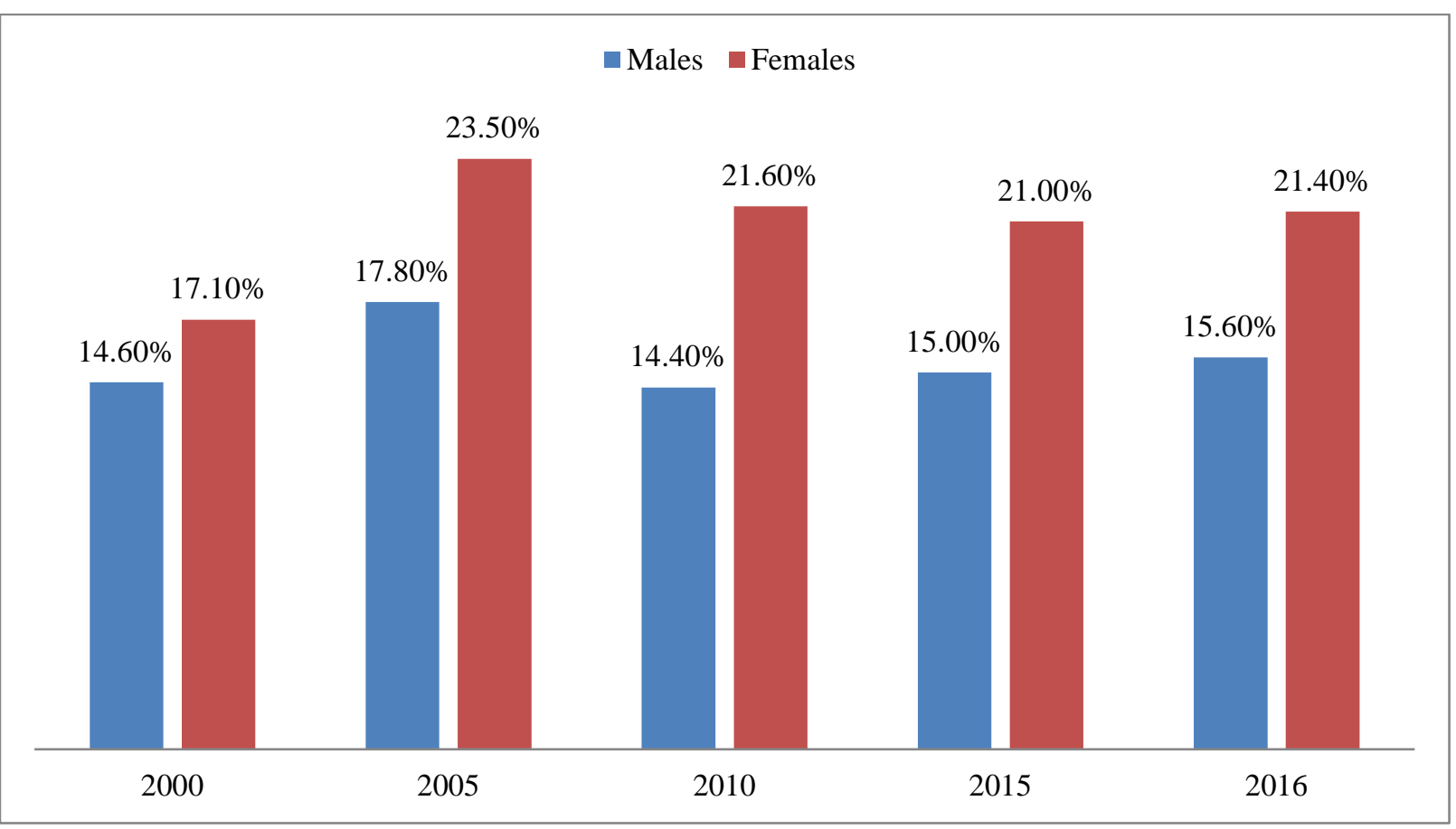

Figure 2. Botswana unemployment by gender

\section{Botswana Unemployment Rate by Gender}

Batswana men have largely enjoyed high education levels than their female counterparts and this has culminated in relatively lower unemployment rates for males (Hope, 1996). However, Hope further goes on to argue that even in cases where females were better educated than males, there seemed to be indications that they encountered barriers to labour force entry. Females were less represented in the formal sector and over represented in the informal sector at 36\% and 75\% respectively (Jefferis, 1993; Hope, 1996). Figure 2 shows that between 2000 and 2016 female unemployment was always higher than male unemployment. Female unemployment increased from $17.1 \%$ to $21.4 \%$ (an increase of $4.3 \%$ ), while male employment increased from $14.6 \%$ to $15.6 \%$ (an increase of only 1\%). This disparity confirms Hope (1996)'s sentiments that males in Botswana find it easier to break into the labour market as compared to their female counterparts. Shinohara (2011) reiterated that the dominant and traditional role of men in generating income in urban and rural households is one of the key reasons behind the relatively high unemployment rates among women. This is perpetuated by wrong cultural and traditional beliefs that the women's role is child bearing and looking after the family (Diraditsile and Ontetse, 2017).

Africa has a total of 9/54 nations which are upper middle income countries. Botswana is one of the three southern countries in southern Africa having an upper middle income country title along with Namibia and South Africa. Figure 3 shows the GDP per capita growth vis-à-vis economically active population growth in Botswana, Namibia and South Africa between 2000 and 2016.

To ensure that data are internationally comparable, part of employment indicators which include economically active population are calculated on age group 15-64 (ILO, 2014). Figure 3 shows that for all the aforementioned three middle income countries, economically active population has been constantly increasing while GNI per capita has been fluctuating and rather on the low side.

This shows that although these emerging nations have been experiencing rapid economic growth, because of increasing economically active population, job creation might not be sufficiently guaranteed. Jefferis and Kelly (2007); and Curry (1987) both affirm that the decline in the agricultural sector in Southern Africa has had adverse consequences both in terms of income generation and employment generation. Malema (2011) also pointed out that the failure by Botswana to generate employment opportunities both within the public and private sectors has been a challenge. Malema's sentiments were echoed by Sechele (2015) when he observed that it was apparent that the formal sector that has been the key employer over the years was unable to generate enough jobs. Economic growth is necessary to employ all those who seek work. However, without sufficient economic growth, people looking for work will be unable to find it (Acemoglu et al., 2001). Nonetheless, in a jobless growth economy with continued increase in economically active populace, unemployment could remain stubbornly high even as the economy grows (Ajilore and Yinusa, 2011).

Another important aspect worth mentioning is the size of the populations of the countries under investigation. South Africa has a huge population of close to 60 million inhabitants while Botswana and Namibia have just above 


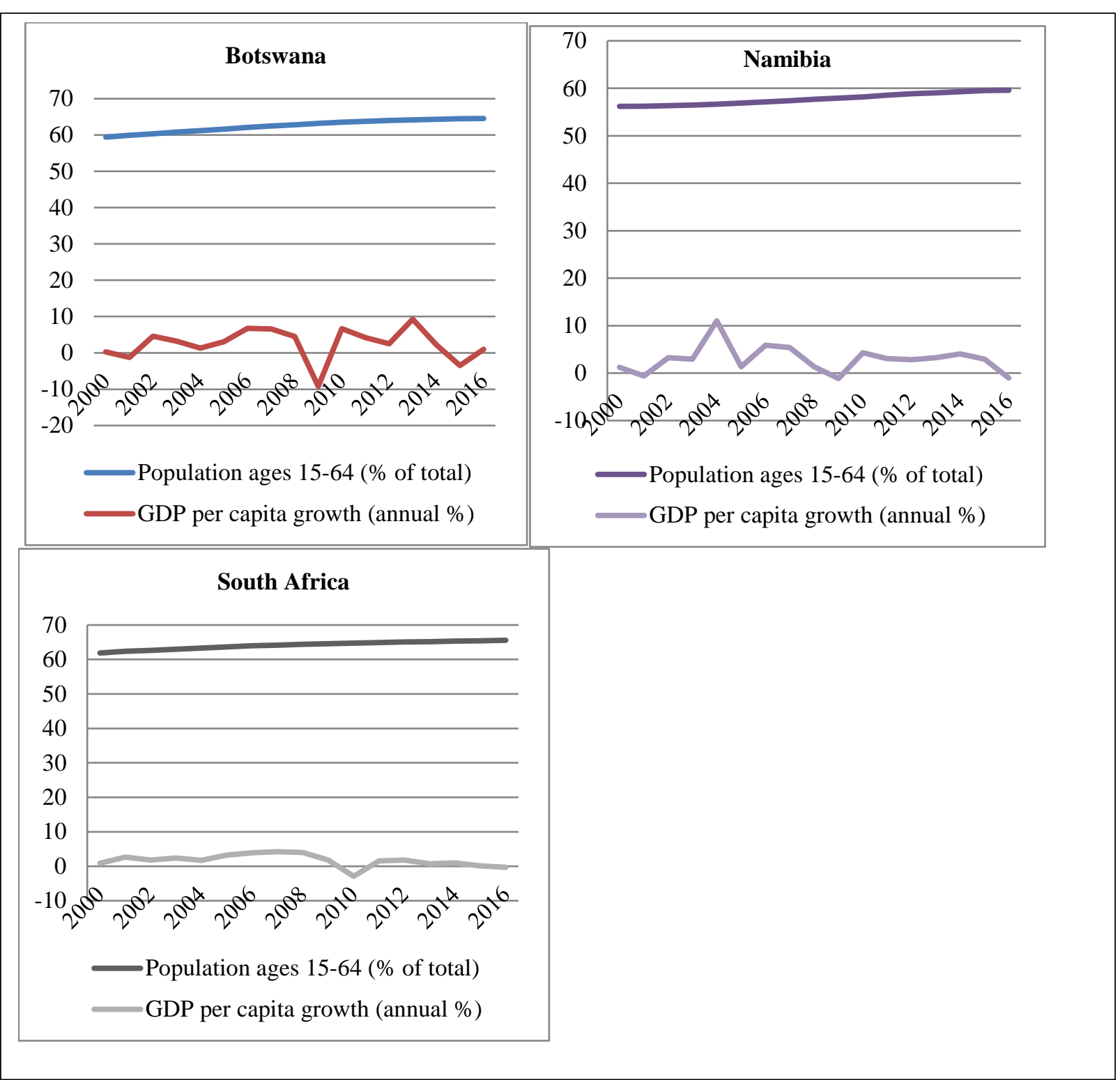

Figure 3. GDP per capita growth vs Economically active population growth

2 million and close to 3 million respectively. Population size, structure and distribution can have significant influence on the unemployment rate (Bogale, 2014). South Africa's population is mainly affected by a huge number of youth who are mostly dependent on the working age group. This impedes the development process as the marginal propensity to consume is very high limiting savings and thus investments (Sechele, 2015). The majority of the population in South Africa is also in rural areas where jobs are not available, with seasonal unemployment a major problem for the few who have them (World Bank, 2017). This has a catalytic factor on unemployment rate. On the other hand Botswana and Namibia have less population. A smaller population is easier to manage as compared to a huge population. Also resources can be better distributed equally to a smaller populace given that a country has prudent management policies, democracy and good governance (Bogale, 2014). Such are characteristics of both Botswana and Namibia.

\section{Unemployment Rate Botswana, Nambia and South Africa}

Comparably as shown in Figure 4, Botswana has always had a lower unemployment rate than Namibia and South Africa between 2000 and 2016. This could be attributed to Botswana's phenomenal economic growth rate compared to Namibia and South Africa as shown in Figure 3.

A combination of prudent fiscal management, pragmatic policy making, good governance and a professional public service enabled Botswana to attain high levels of economic growth and access to public services when compared to other countries with comparable or better resource endowments (Kaunda, 2008). This could explain why Botswana has managed to maintain a lower unemployment rate comparably with Namibia and South Africa. 


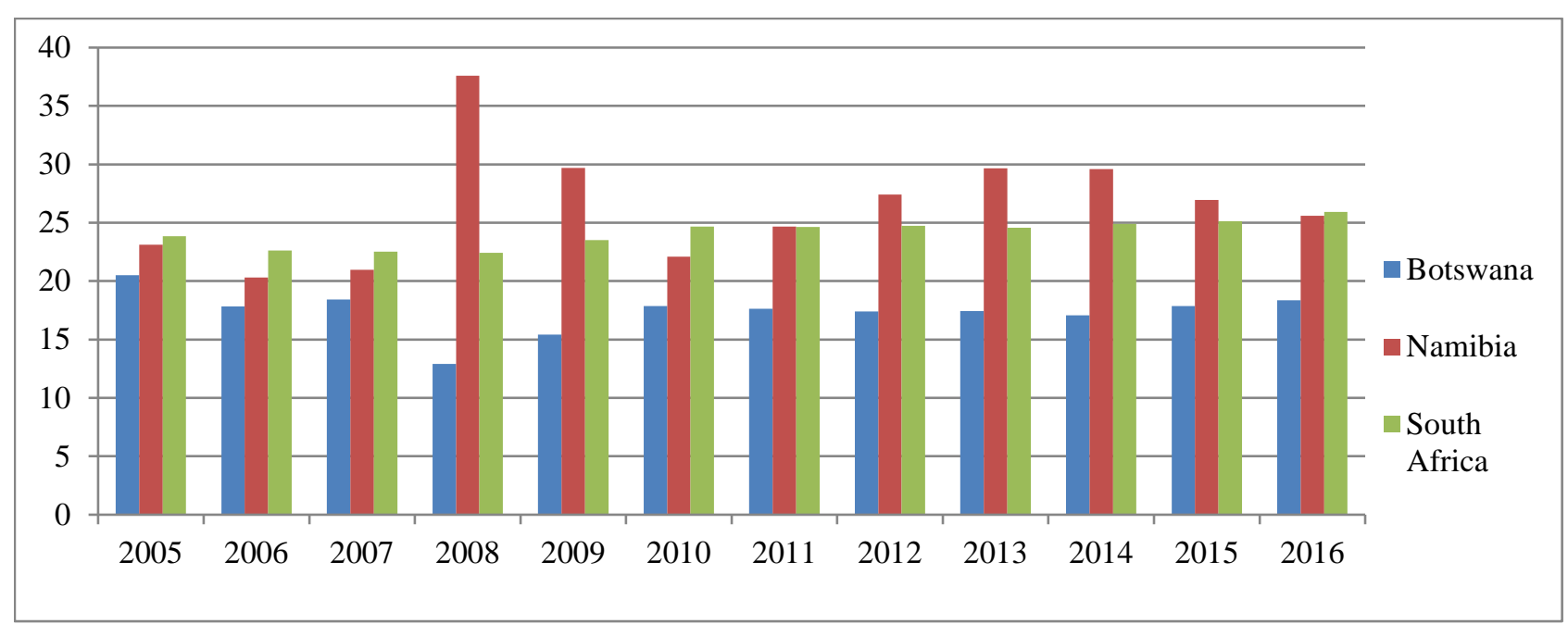

Figure 4. Unemployment rate (\%) in Botswana, Namibia \& South Africa

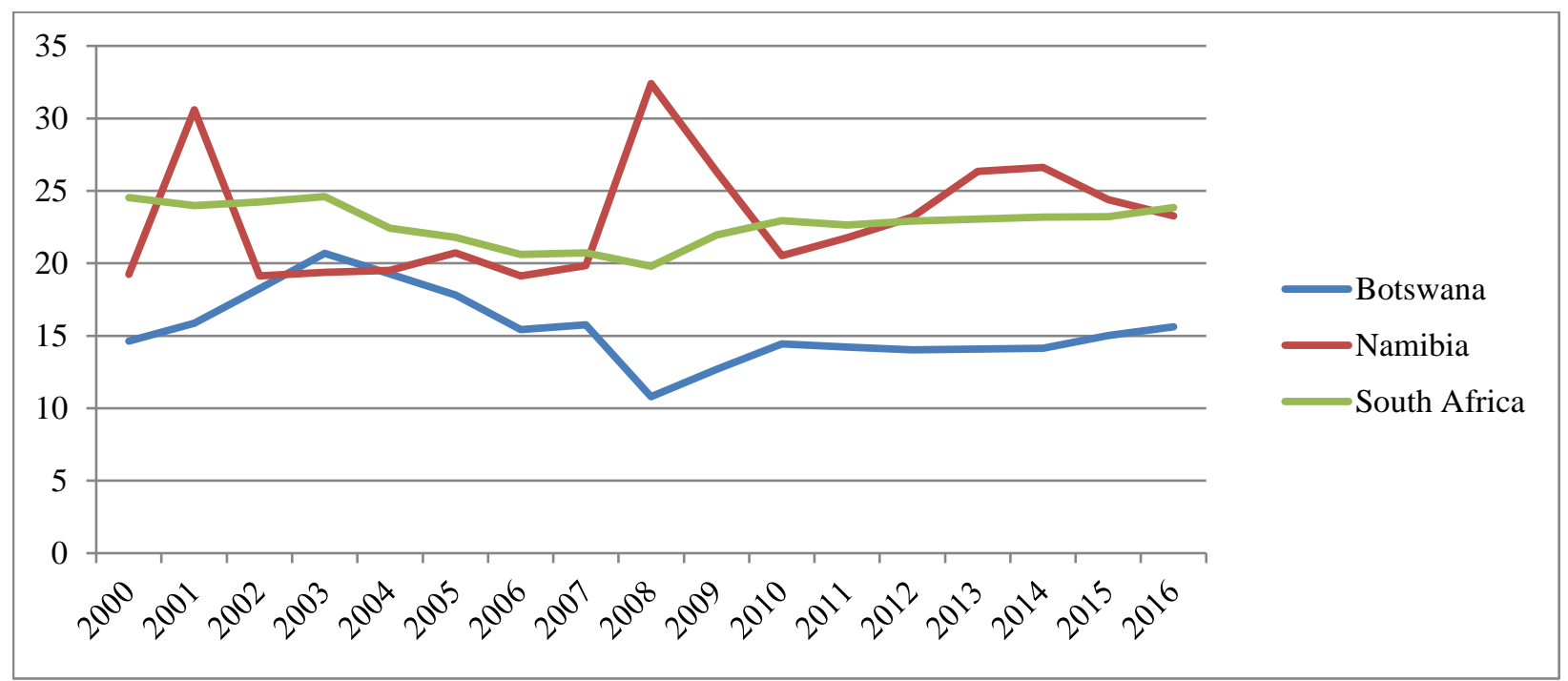

Figure 5. Unemployment, male (\% of male labor force)

\section{Male Unemployment Rate}

Figure 5 shows the male unemployment rate trends for Botswana, Namibia and South Africa between 2000 and 2016. Botswana has managed to maintain a lower male unemployment rate comparably with Namibia and South Africa. This can be attributed to the ease of entry into the labour market for male Batswana populace. This is also aided by the early male entry into the labour market (Siphambe, 2003).

\section{Female Unemployment Rate}

Female unemployment in all the countries is notably higher than male unemployment between 2000 and 2016. However Figure 6 attests Botswana having lower female unemployment rates as compared to Namibia and South Africa.

\section{Youth Unemployment Rate}

Youth unemployment is considered to be a major concern among officials and politicians in Botswana (Sechele, 2015). Botswana has had a significant increase in youth unemployment, from a low of $13.6 \%$ in 2000 to a high of $33.3 \%$ in 2016 (an increase of 19.7\%), as shown on Table 1.

Youth unemployment is a particularly serious concern in Botswana because the country is experiencing a youth bulge (AfDB/OECD 2003), which presents opportunities for growth if young people are meaningfully in employment (Siphambe, 2007), and the probable for grave socio-economic instability if they are not (Mogomotsi et al., 2017). More generally there are a plethora of causes as to why unemployment is a negative phenomenon, from modest welfare effects, to grim output effects and other socioeconomic and political consequences (Lekorwe et al., 2017). Malema (2011) reiterated that unemployed youth in Botswana are generally low-skilled and have little experience of employment, with two thirds of young people having never worked. The youth are obviously 


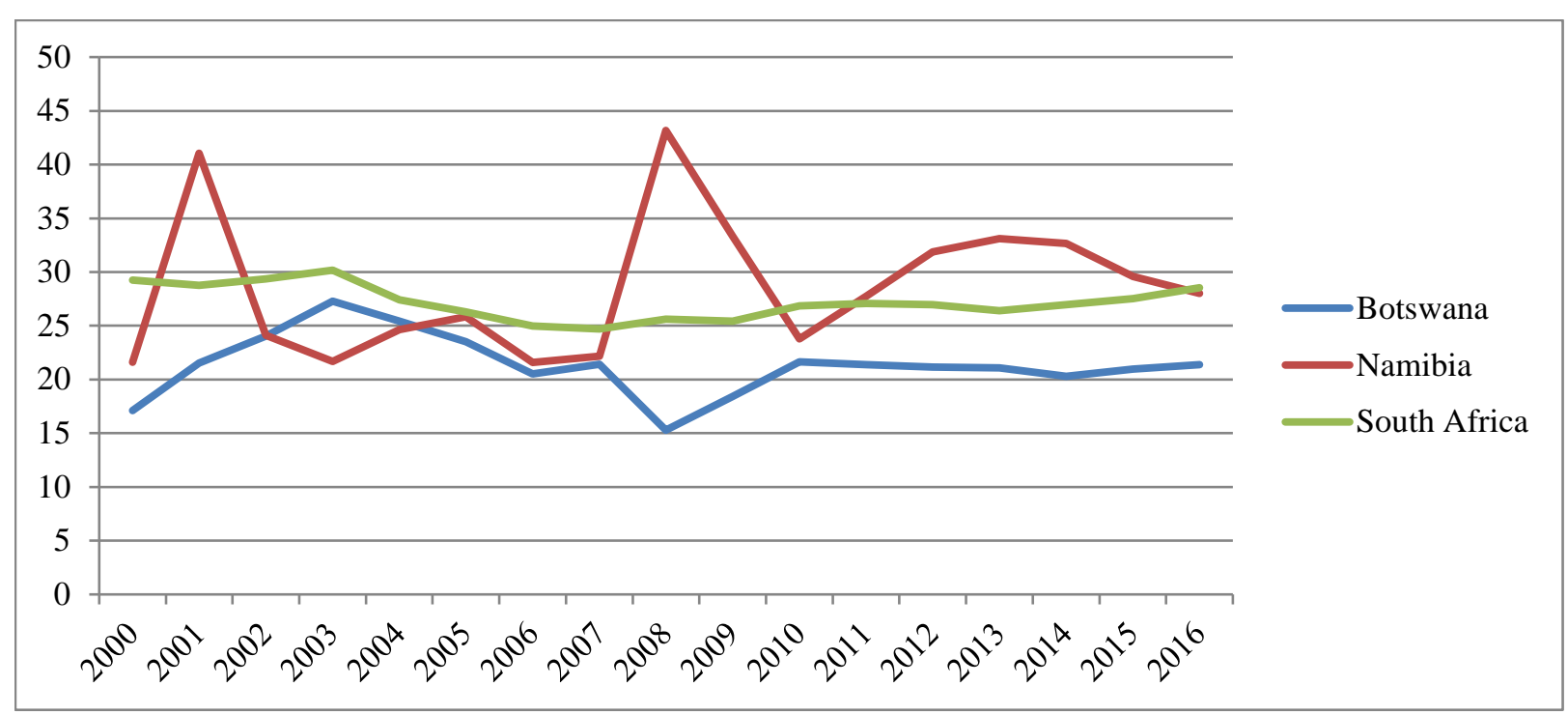

Figure 6. Unemployment, female ( $\%$ of female labor force)

Table 1. Unemployment, youth total (\% of total labor force ages $15-24)$

\begin{tabular}{lllll}
\hline & $\mathbf{2 0 0 0}$ & $\mathbf{2 0 0 5}$ & $\mathbf{2 0 1 0}$ & $\mathbf{2 0 1 6}$ \\
\hline Botswana & 13.6 & 35.8 & 33.8 & 33.3 \\
\hline
\end{tabular}

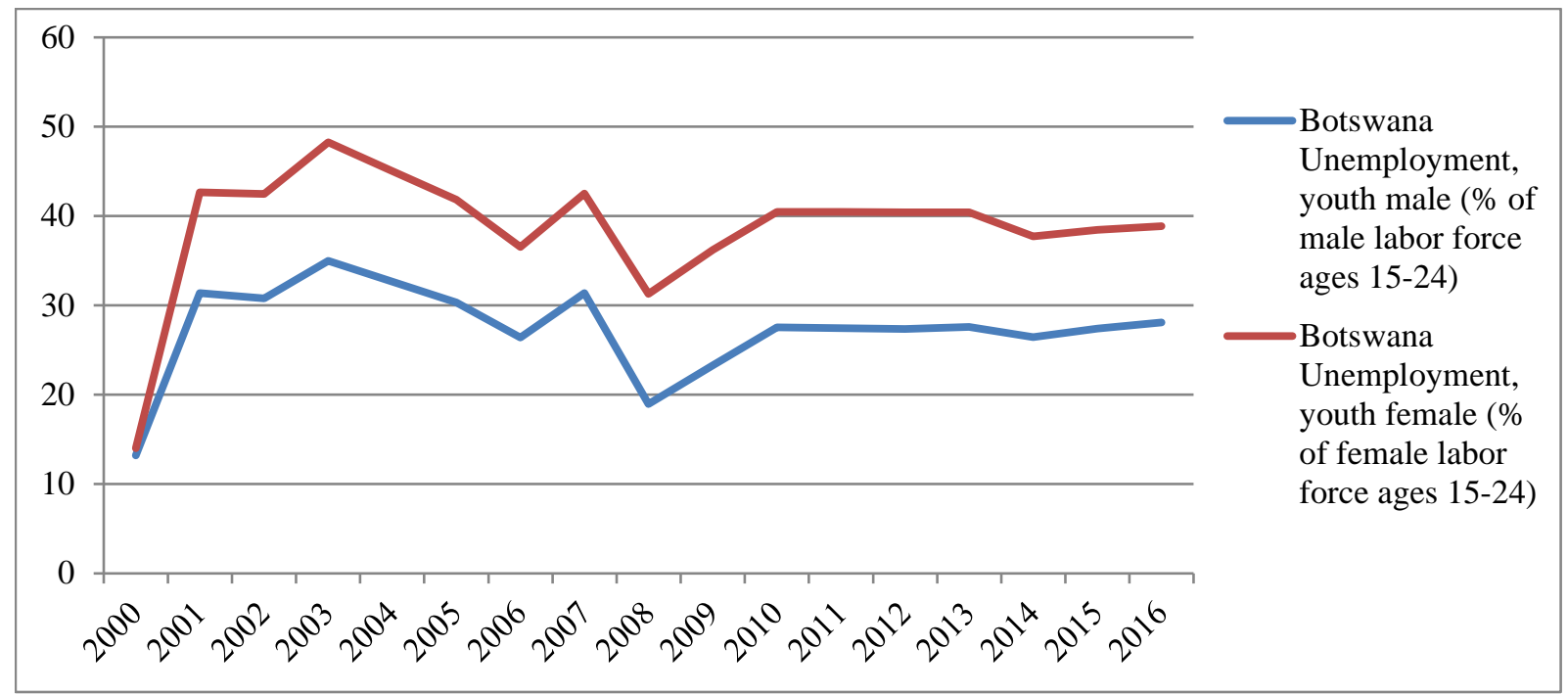

Figure 7. Botswana male and female youth unemployment rate (\%)

unemployed because they have lower on-the-job experience, some of the issues could also be due to their late entry into the labour market compared to the older cohort (Nthomang and Diraditsile, 2016).

\section{Botswana Youth Unemployment by Gender}

Figure 7 highlights a continuous trend of higher female unemployment rate than male unemployment rate in Botswana from 2000 to 2016. The gap between youth female unemployment and youth male unemployment has also been relatively wide and almost constant (reaching 13.3\% in 2003 and 12.9\% in 2010). Thus, Botswana has not done much in reducing the gap between youth female unemployment and youth male unemployment over the years. Tradition and culture could also have contributed to the marginalization of youth females as they are expected to get married, bear kids and look after the family (Siphambe and Okurut, 2011).

\section{Youth Unemployment Rate: Botswana, Namibia \& South Africa}

High rates of joblessness among young people have been explained in two quite different ways. The traditional view holds that the problem is one of job availability. A general shortage of openings makes it very difficult for young workers to find jobs. It takes the unemployed a long time to find a job. The "new" view sees employment instability as the crux of the joblessness problem. It treats the large flow of graduates into unemployment rather than the long length of unemployment spells as the crucial symptom of the problem (Garcia, 2011; Okurut and Ama, 2013). 


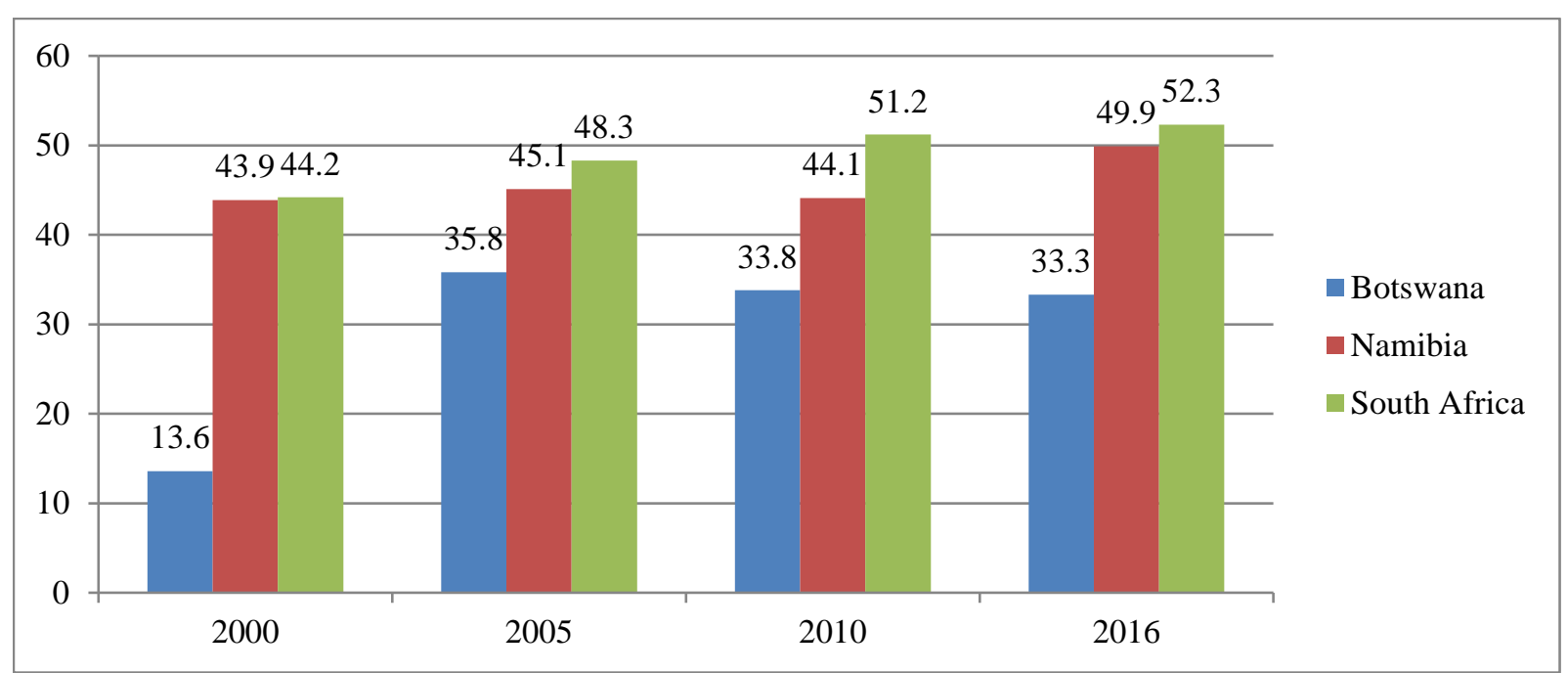

Figure 8. Unemployment, youth total (\% of total labor force ages 15-24)

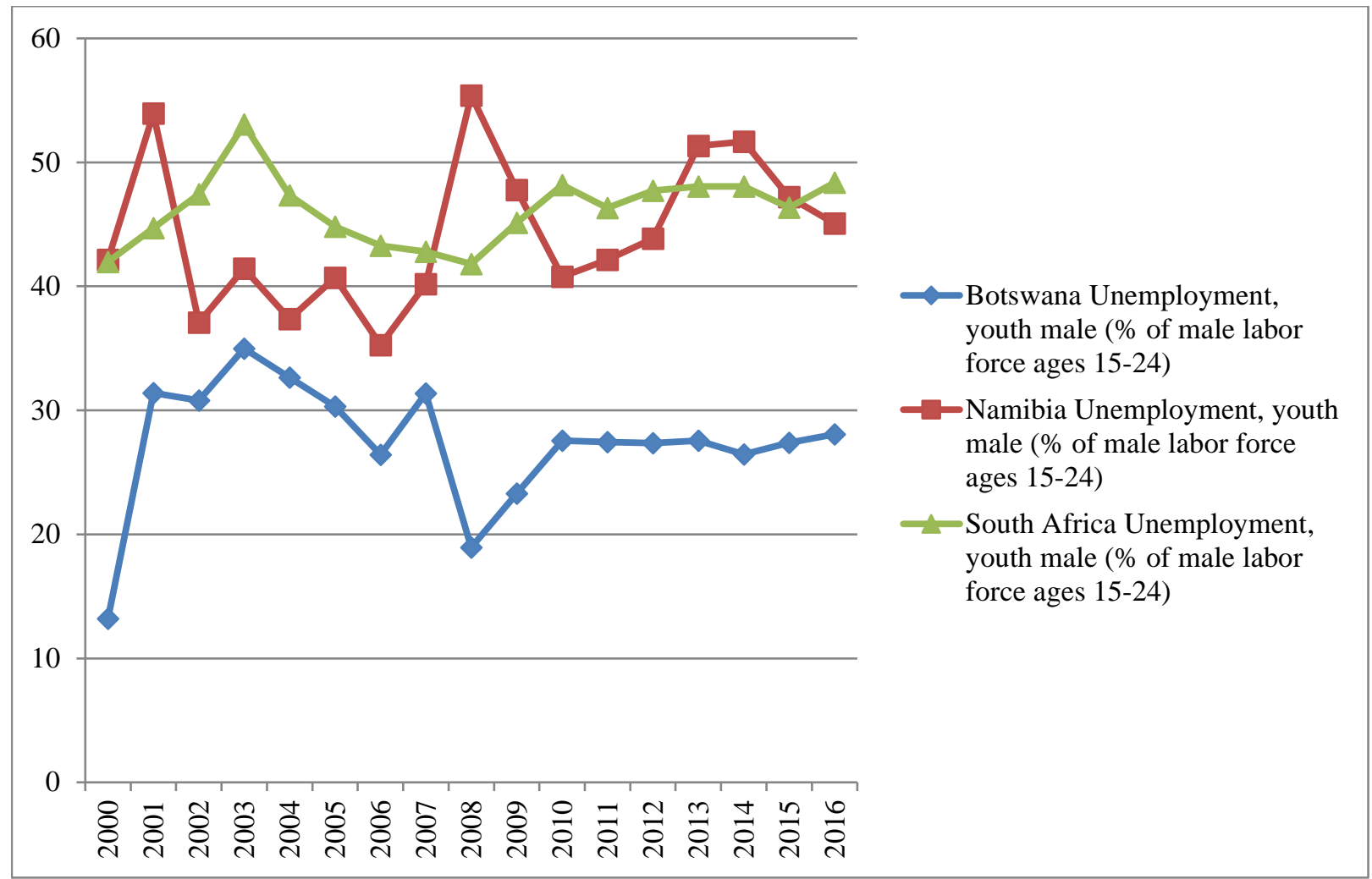

Figure 9. Male youth unemployment rate

Figure 8 shows that although Botswana's youth unemployment rate has considerably increased, Botswana has managed to maintain a lower youth unemployment rate as compared to Namibia and South Africa.

\section{Male Youth Unemployment Rate}

Botswana has also maintained a lower male youth unemployment rate as compared to Namibia and South Africa.

\section{Female Youth Unemployment Rate}

On the other hand, South Africa has maintained a lower female youth unemployment rate as compared to Botswana and Namibia.

\section{Total Unemployment vs. Youth Unemployment}

Figure 11 exhibits that youth unemployment is higher against total unemployment rate for all the upper middle income countries under study. Botswana has 33\% against 18\%, Namibia has $49 \%$ against $25 \%$ and South Africa 


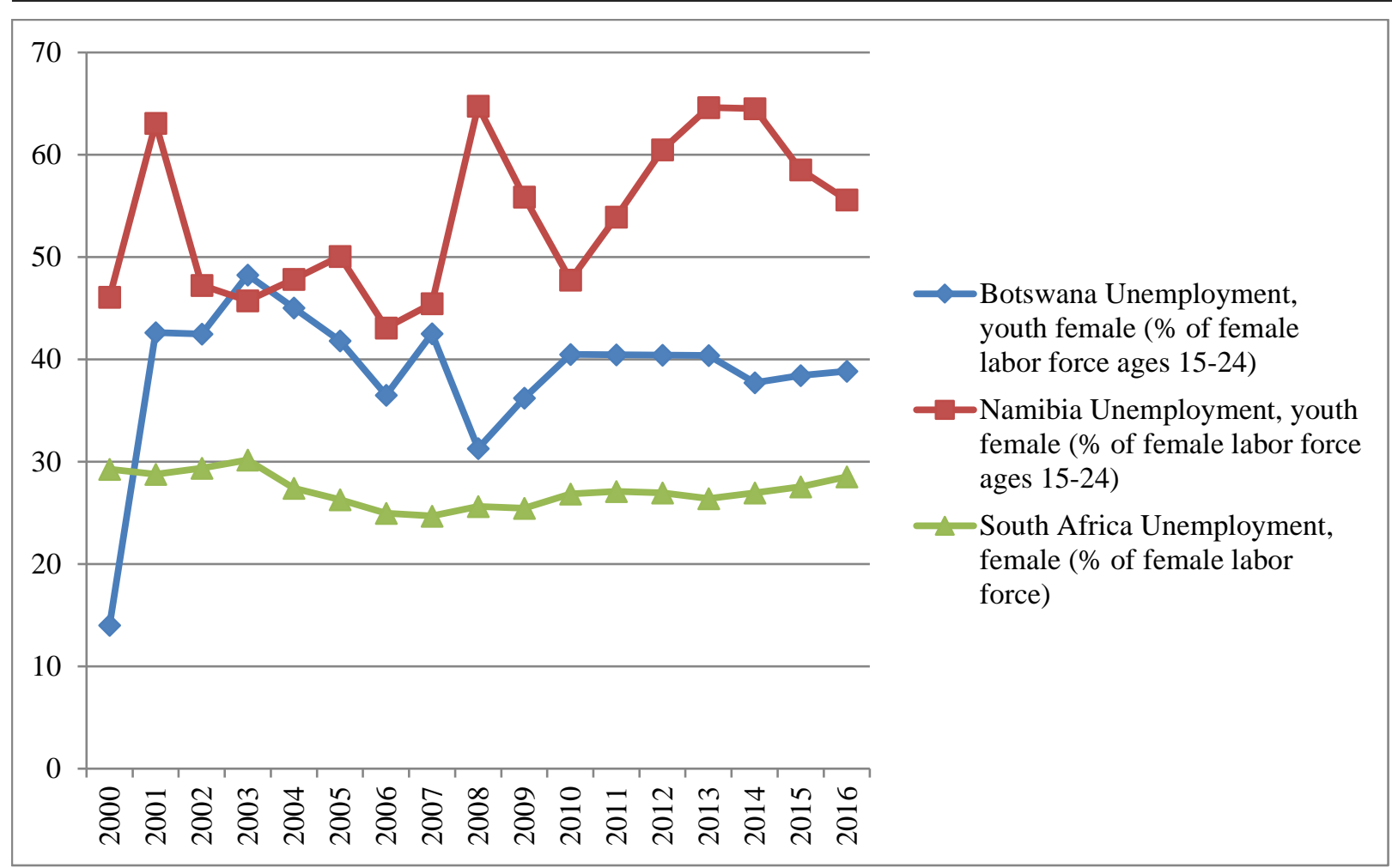

Figure 10. Female youth unemployment rate

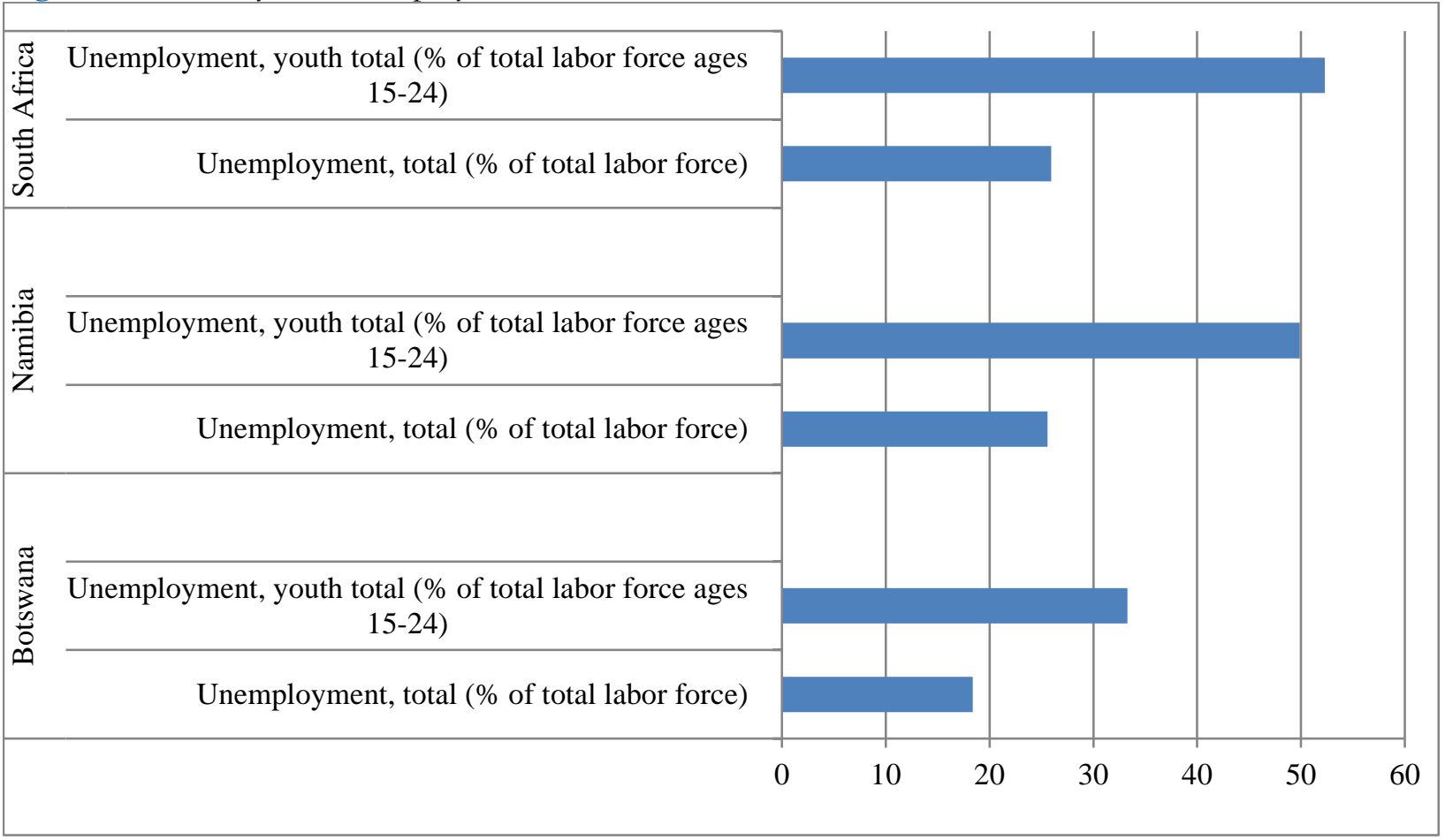

Figure 11. Unemployment, total (\% of total labor force) vs Unemployment, youth total (\% of total labor force ages 15-24), (2016)

has $52 \%$ against $25 \%$. This confirms the dire situation these countries are facing regarding youth unemployment. Nevertheless, Botswana still maintains a lower total unemployment rate against total youth unemployment rate than Namibia and South Africa. The oversupply of university graduates and the resulting qualification not only helps to explain the extent of youth unemployment rate among graduates, but also the level among those youngsters with the lowest level of education (Siphambe, 2004). The gap between total unemployment rate and youth unemployment rate is exacerbated by young individuals entering the labor market each year with only a small portion of graduates finding employment; worsening youth unemployment rate. 


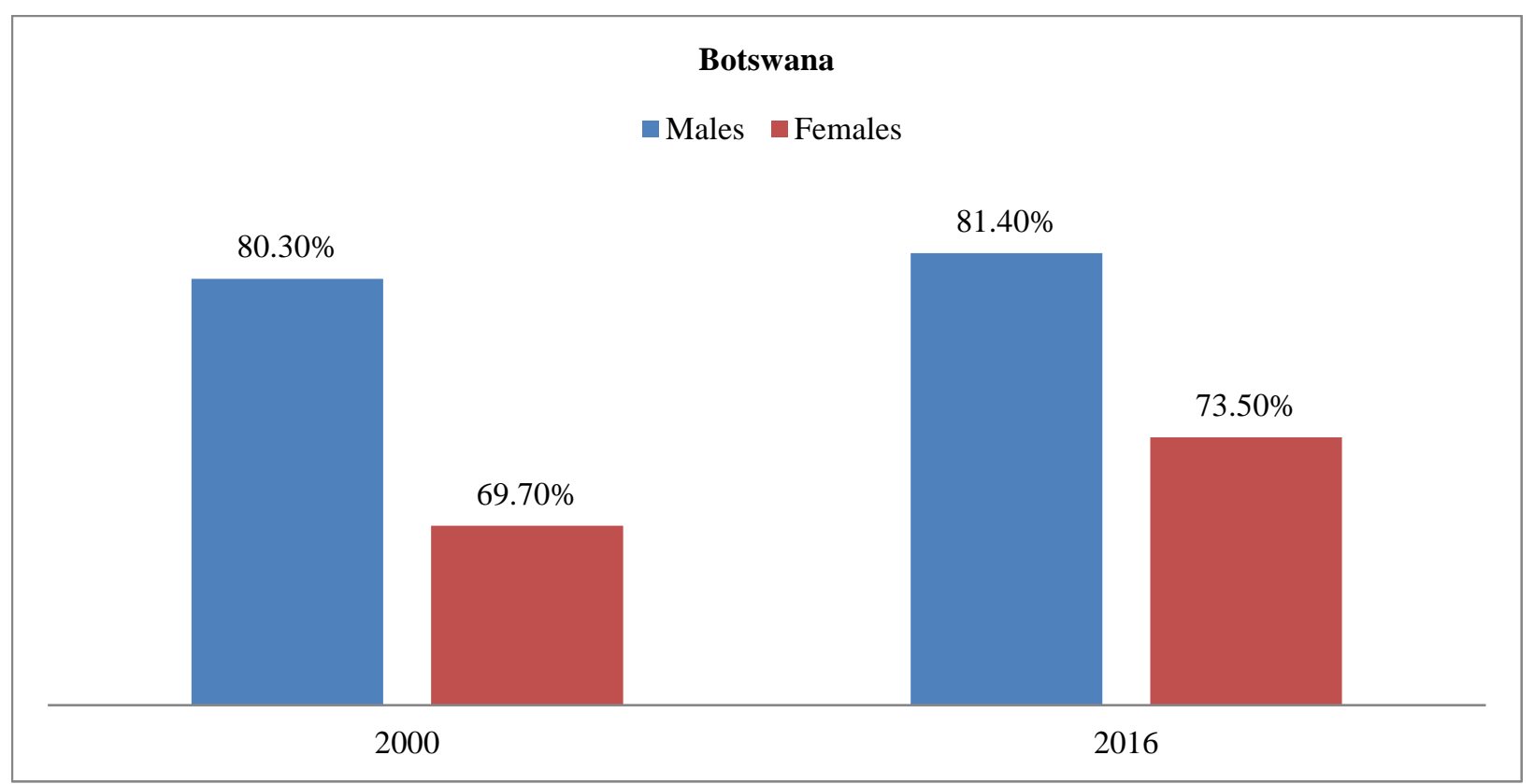

Figure 12. Botswana labour force participation (male vs female)

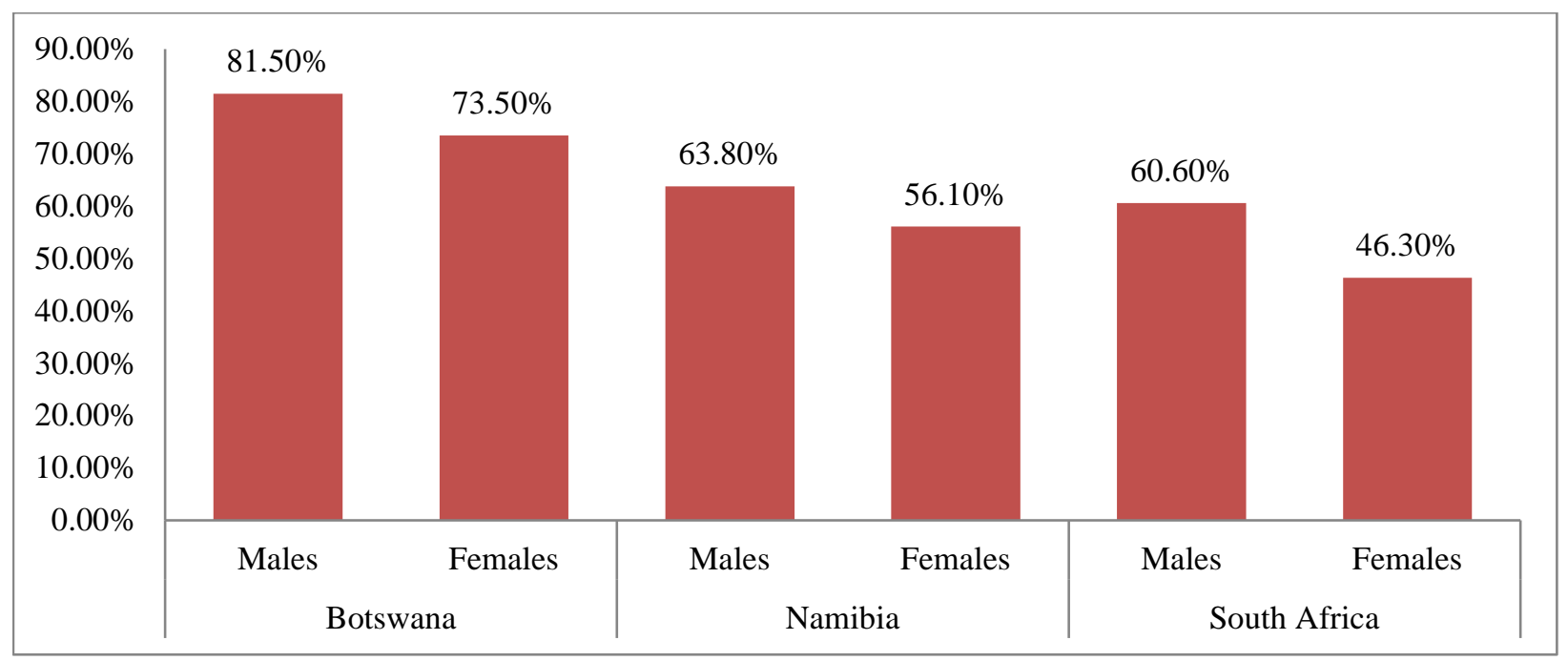

Figure 13. Labour force participation \% (male vs female)

\section{Botswana Labour Force Participation by Gender}

The labour force participation rate is calculated as the labour force divided by the total working-age population. The working age population refers to people aged 15 to 64 (UN, 2002). Labor force participation rate is also defined as the percentage of the population that is of working age and are also members of the work force. In other words, it is the percentage of able working people who actually have jobs and are working. This rate is important because it gives a measure of how active the economy's labor force is and also sheds light on the true employment rate (ILO, 2017). Figure 12 shows that female labour force participation has been lower than male labour force participation in Botswana. However, the gap has narrowed from $10.6 \%$ in 2000 to $7.9 \%$ in 2016. This highlights the government efforts to break traditional and cultural connotations which inhibited women entry into the labour market.

\section{Labour Force Participation by Gender}

Botswana has the highest labour force participation by gender as compared to Namibia and South Africa. Labour force participation (LFP) rate for females is far lower than for their male counterparts in all the three countries as shown in Figure 13. This explains the high rate of unemployment among females in these countries. 


\section{CONCLUSION AND RECOMMENDATIONS}

Statistics reviewed in this paper revealed that Botswana labour market is characterized by high and increasing unemployment rate especially since 2008. Of such high unemployment rate, female unemployment rate is higher than male unemployment rate. It should also be noted that Botswana's economically actively population growth is increasing significantly faster than GDP per capita growth. Furthermore, youth unemployment in Botswana has considerably increased over the years. Female youth unemployment rate in Botswana is higher than male youth unemployment rate. Regarding labour force participation, males in Botswana have higher labour force participation than females.

Comparing the analyzed statistics with Namibia and South Africa, this paper concludes that Botswana has significantly lower levels of total unemployment, male unemployment, female unemployment, total youth unemployment and youth male unemployment rate than Namibia and South Africa. This as highlighted in the literature above can be attributed to prudent macroeconomic policies, reinvestment of revenue from diamond minerals and the government's commitment in enhancing good governance, economic growth and economic development. Comparably with these similar emerging-market economies all the reviewed countries have higher male labour force participation than females and also higher youth unemployment rate than total unemployment rate. South Africa should be commended for having lower youth female unemployment rates compared with Botswana and Namibia. This study thus concludes that unemployment in Botswana, Namibia and South Africa is therefore concentrated among women and the youth. Unemployment among these groups has reached crisis levels and generally exceeds national average rates.

The paper recommends that:

- These upper middle income countries should navigate their economic path and employment policies in a way that prioritizes the high and escalating number of youth and women on the payroll. Clearly, there is a strong case for governments and other stakeholders to put in place policies that encourage, persuades or motivate employers, particularly in the private sector, to recruit the youth and women.

- These countries should ensure that their demographic transition allows resources not to be absorbed and overshadowed by population growth.

- Governments should adequately create sustainable employment opportunities for graduates, and other youth especially females.

- There is indeed urgent need of investing in relevant training and skills development which meets employers' needs as the main levers to fight unemployment and overcome the current mismatch in the labour market.

- For Botswana, Namibia and South Africa, with further human capital formation, technological development with a focus on labour intensive industries like textiles, construction, tourism, agriculture and manufacturing sectors, and a structural change of the economy, might be able to reverse the effects of unemployment across age and gender. A move away from dependence on few industries is recommended.

\section{LIMITATIONS OF THE STUDY AND SUGGESTIONS FOR FUTURE RESEARCH}

The study inferred comparisons from general trend analysis of the statistical data of Botswana, South Africa and Namibia. This limits the possibility of analyzing impact of unemployment on growth and vice versa as well as inferences on causality directions. An econometric approach is thus recommended in order to be able to discern more important inferences. Single country analysis can also give a better outlook of the dynamics in these countries as they differ in size and industry structure. A critical interrogation of the effects of other variables like poverty rate, trade balance, migration, etc on unemployment can also enrich further studies.

\section{REFERENCES}

Acemoglu, D., Johnson, S. and Robinson, J. A. (2001). An African Success Story: Botswana. Centre for Economic Policy Research. London.

AFDB. (2018). Growth, Jobs and Poverty. AFDB.

AfDB/OECD. (003). African Economic Outlook: Botswana. AfDB/OECD.

Ajilore, T. and Yinusa, O. (2011). An Analysis of Employment Intensity of Sectoral Output Growth in Botswana. Southern African Business Review, 15(2), 26-42. 
Assar, L. and Snower, D. (1986). Wage Setting, Unemployment, and Insider-Outsider Relations. American Economic Review, 76(2), 235-239.

Bogale, M. P. (2014). Curbing Unemployment in Africa (Botswana) by Incorporating Entreprenuership Training in the Education System. African Perspectives.

Costas, A. and Stiglitz, J. (1983). Implicit Contracts and fixed Price Equilibria. The Quarterly Journal of Economics, XCVIII Supplement.

Curry, R. L. (1987). Poverty and Mass Unemployment in Mineral-rich Botswana. American Journal of Economics and Sociology, 46(1). https:// doi.org/10.1111/j.1536-7150.1987.tb01764.x

Diraditsile, K. and Ontetse, M. A. (2017). Lived Experiences and Consequences of Unemployment on Women: An Emprirical study of Unemployed Young Women in Mahalapye, Botswana. Journal of International Women's Studies, 18(4), 131-143.

Frank, C. R. (1968). Urban Unemployment and Economic Growth in Africa. Oxford Economic Papers, 20(2), 250274. https://doi.org/10.1093/oxfordjournals.oep.a041095

Garcia, R. G. (2011). Youth unemployment in Spain: causes and solutions. Working Papers Number 11/31. Economic Analysis, BBVA Research, Madrid.

Hope, Sr. K. R. (1996). Growth, Unemployment and Poverty in Botswana. Journal of Contemporary African Studies, 14(1), 53-67. https://doi.org/10.1080/02589009608729581

ILO. (2012). Global Employment Trends for Youth 2012: A Generation at Risk. International Labour Organization. Geneva.

ILO. (2014). Global Employment Trends for Women. International Labour Organization. Geneva.

ILO. (2017). Labour Force Estimates and Projections. International Labour Organization, Geneva.

Jefferis, K. R. and Kelly, T. F. (2007). Botswana: Poverty amid Plenty. Oxford Agrarian Studies, 27(2), 211-231. https:// doi.org/10.1080/13600819908424174

Kaunda, J. M. (2008). The Progress of Good Governance in Botswana. Gaborone: BIDPA and UNECA.

Lekorwe, M., Moseki, K. and Mokaloba, M. (2018). Unemployment Mars Favourable Assessment of Batswana Government Performance. Afrobarometer Dispatch No. 184. IJR.

Malema, B. W. (2011). Unemployment and the attribute of the Unemployed in Botswana. Botswana Notes and Records, 46, 58-71.

Mogomotsi, G. E. J., Madigele, P. K. and Chamberlain, J. M. (2017). A Cursory Discussion of Policy Alternatives for Addressing Youth Unemployment in Botswana. Cogent Social Sciences, (3)1.

Mohr, P., Fourie, L. and associates. (2008). Economics for South African students. 8th Edition. Van Schaik, Pretoria.

Nthomang, K. and Diraditsile, K. (2016). Youth Unemployment in Botswana: Understanding the journey travelled so far. Mosenodi Journal of the Botswana Educational Research Association, 19(1).

Okurut, F. N. and Ama, N. O. (2013). Assessing factors that affect women and youth micro-entrepreneurs in Botswana. International Journal of Academic Research in Economics and Management, 2(1), 306-332.

Osei-Hwedie, K. (2003). Unemployment in Botswana: Implications for Vision 2016. A paper presented at University of Botswana. Gaborone.

Sechele, L. (2015). In their own words: Unemployed young people on tackling Youth Labour Market Entry Constraints in Botswana. Journal of Sociological Research, 6(2), 56-67. https://doi.org/10.5296/jsr.v6i2.8073

Shinohara, N. (2011). Confronting Emerging Challenges in Botswana. International Monetary Fund.

Siphambe, H. K. and Okurut, N. (2011). The Demand for Skills in Botswana: Final Report Submitted to World Bank. Background paper prepared for the World Bank study, Labor Market Signals of the Demand for Skills. University of Botswana, Gaborone.

Siphambe, H. K. (2003). Understanding Unemployment in Botswana. South African Journal of Economics, 71(3), 48095. https://doi.org/10.1111/j.1813-6982.2003.tb00082.x

Siphambe, H. K. (2004). Botswana's Economy and Labour Market: Are there any Lessons for SADC for Regional Integration? Development Southern Africa, 21(2), 353-64. https://doi.org/10.1080/0376835042000219578

Siphambe, H. K. (2007). Growth and employment dynamics in Botswana: A case study of policy coherence. Working Paper No. 82. International Labour Office, Policy Integration and Statistics Department, Geneva.

Skidelsky, R. (1992). John Maynard Keynes: The Economist as Savior 1920-1937. London: MacMillan London Ltd.

Soylu, O. B., Çakmak, I. and Okur, F. (2018). Economic Growth and Unemployment Issue: Panel Data Analysis in Eastern European Countries. Journal of International Studies, 11(1), 93-107. https://doi.org/10.14254/20718330.2018/11-1/7

Sutherland, P. (2015). Migration is development: How Migration Matters to the Post 2015 Debate. Migration and Development, 2, 151-156. https://doi.org/10.1080/21632324.2013.817763

UN. (2002). Labour market: Definitions. United Nations System of National Accounts. UN.

World Bank. (2017). 2017 List of Low, Lower Middle and Upper Middle Income Economies. $38^{\text {th }}$ Annual Conference of International Society of Clinical Biostatistics. ILO, Geneva. 